\title{
Law Compliance Against Perpetrators of Covid-19's Forced Retrieval
}

\begin{tabular}{|c|c|}
\hline \multicolumn{2}{|c|}{$\begin{array}{l}\text { Endang Yuliana Susilawati1, Tabah Budi Prasetyo }{ }^{2} \\
\text { 1.2Faculty of Law, Universitas Slamet Riyadi, Surakarta, Indonesia }\end{array}$} \\
\hline Info Artikel & Abstract \\
\hline $\begin{array}{l}\text { Keywords: } \\
\text { Law Enforcement; Covid- } \\
\text { 19; The Force Bodies } \\
\text { Covid-19 }\end{array}$ & $\begin{array}{l}\text { The spread of Corona Virus Disease } 2019 \text { (COVID-19) in Indonesia is now } \\
\text { increasing and extending across regions and across countries. The increase has } \\
\text { resulted in death, decline and economic slowdown (recession), disrupted } \\
\text { educational, economic and social activities, and most concerned about the } \\
\text { psychological impact and behavioral changes on society. Like the case of coaxial } \\
\text { corpse-19 corpse taking, this was the impact of the lack of effective socialization, } \\
\text { education and communication from the government to the community and the } \\
\text { hospital to the family /community. In this case, law enforcers need to participate } \\
\text { in educating and disseminating to the public effectively and acting decisively } \\
\text { against people who insist on violating applicable health regulations / protocols. } \\
\text { Law enforcement can be done in a humane and solutive manner so as not to cause } \\
\text { resistance in the midst of society. If the public still insists on violating the coaxial } \\
\text { collection of covid-19 bodies, they may be subject to sanctions such as Article } 93 \\
\text { of Law No. } 6 \text { of } 2018 \text { concerning Health Quarantine jo Article 211, 212, } 214 \text { of } \\
\text { the Criminal Code, Article } 335 \text { of the Criminal Code, with a penalty of up to } 7 \\
\text { (seven) years prison and Article } 336 \text { paragraph } 1 \text { and } 2 \text { of the Criminal Code. This } \\
\text { paper aims to review and discuss the rule of Law enforcement the suspect the force } \\
\text { bodies covid-19. }\end{array}$ \\
\hline & Abstrak \\
\hline $\begin{array}{l}\text { Kata kunci: } \\
\text { Penegakan hukum; Covid- } \\
\text { 19; Pengambilan paksa } \\
\text { jenazah. }\end{array}$ & $\begin{array}{l}\text { Penyebaran Corona Virus Disease } 2019 \text { (COVID-19) di Indonesia saat ini sudah } \\
\text { semakin meningkat dan meluas lintas wilayah dan lintas negara. Peningkatan } \\
\text { tersebut berdampak kematian, penurunan dan pelambatan ekonomi (resesi), } \\
\text { terganggu aktifitas pendidikan, ekonomi dan sosial, dan yang paling } \\
\text { mengkhawatir dampak psikologis dan perubahan perilaku pada masyarakat. }\end{array}$ \\
\hline Corresponding Author: & Seperti kasus pengambilan paksa jenazah covid-19 ini merupakan dampak dari \\
\hline $\begin{array}{l}\text { Endang Yuliana Susilawati, } \\
\text { E-mail: } \\
\text { endangyuliana@gmail.com }\end{array}$ & $\begin{array}{l}\text { kurangnya sosialısasl, edukasi dan komunikasi yang efektif balk darl pihak } \\
\text { pemerintah terhadap masyarakat maupun pihak rumah sakit terhadap pihak } \\
\text { keluaga/masyarakat. Demikian penegak hukum perlu ikut serta dalam } \\
\text { mengedukasi dan mensosialisasikan kepada masyarakat secara efektif serta } \\
\text { bertindak tegas terhadap masyarakat yang bersikeras melanggar } \\
\text { peraturan/protokol kesehatan yang berlaku. Penegakan hukum dapat dilakukan }\end{array}$ \\
\hline P-ISSN: 1412-6605 & secara humanis dan solutifbertujuan agar tidak menimbulkan resistensi di tengah \\
\hline & $\begin{array}{l}\text { masyarakat. Apabila masyarakat masih bersikeras melanggar pengambilan paksa } \\
\text { jenazah covid-19 dapat dikenakan sanksi hukum seperti, Pasal 93 Undang- } \\
\text { Undang No } 6 \text { Tahun } 2018 \text { tentang Kekarantinaan Kesehatan jo Pasal 211, 212, } \\
214 \text { KUHP, Pasal } 335 \text { KUHP, dengan ancaman hukuman hingga } 7 \text { (tujuh) tahun } \\
\text { penjara dan Pasal } 336 \text { ayat } 1 \text { dan } 2 \text { KUHP. }\end{array}$ \\
\hline
\end{tabular}

\section{Introduction}

The spread of the latest COVID-19 (Coronavirus Virus 2019), which became a global epidemic and had a very significant effect on other facets of life, stunned the international community in late 2019. As a international health agency it has been declared a global pandemic by the World Health Organization (WHO). This disease soon became a pandemic in a short time, which spread all over the world. The plague itself is described as a dangerous disease which quickly spreads and 
often causes death. Pest is also a very dangerous disease that can cause a lot of body harm from microscopic species called bacteria. COVID-19 has affected over 210 countries worldwide. News media around the world announce at any time the number of victims that keep on rising from time to time. The virus that was first identified in Wuhan City, Hubei Province, China at the end of 2019 spread so rapidly that it prompted a number of countries to take immediate action to enforce a lockout, including in Indonesia, by blocking all accesses in and out of their territory. ${ }^{1}$

Indonesia is one of the countries affected by this epidemic, but it is fairly slow to identify this virus as it has recently been one of the countries that have been infected after many others. This fact has sparked debate in a number of circles including researchers from Harvard University and WHO itself who have warned Indonesia to immediately carry out mass tests with the aim of suppressing the spread of this virus as quickly as possible. After due consideration, Indonesia then introduced a large-scale social restriction (PSBB) program for some of the worst affected areas, partially or totally. ${ }^{2}$

As of June 15, 2020, official data states that there were 39,294 cases of COVID19 infection in Indonesia, with 21,973 patients diagnosed, 15,123 cases recovered and 2,198 deaths. This number continues to grow when viewed from the statistical curve, and this is why policy makers must take proactive action immediately. The virus has spread to all countries in the world in a matter of months. Nearly every province in Indonesia has reported cases of COVID-19. Furthermore the COVID-19 effect is devastating. The main effect is loss of life or death, economic downturn and stagnation (recession), disruption of educational, economic and social activities and the most troubling psychological and behavioral effects on society. ${ }^{3}$

Some community members have overreacted, and did not even understand the suggested health plan from the government. For example, the family of the patient took the body by force because he did not comply with the COVID-19 protocol to the funeral. The aspect that triggers this case is the lack of socialization, awareness and coordination on the procedure for monitoring COVID-19 bodies, both from the government to the community and the family / community hospital, so that the group doesn't realize the negative impacts that can happen. In this situation, responsible authorities such as law enforcers need to be involved in effectively informing and disseminating them to the public and taking concrete action against citizens who maintain that they breach the relevant health regulations / protocols. When the family continues to insist, the

\footnotetext{
1 Yuliana. 2020. Corona Virus Diseases (Covid-19): sebuah tinjuan literatur. Wellness And Healthy Magazine Vol.2, No.1, Februari (187-192).

${ }^{2}$ Hukumonline.com

${ }^{3}$ Ivan Muhammad Agung, Memahami Pandemi Covid-19 dalam Perspektif Psikologi Sosial. Psikobuletin: Buletin Ilmiah Psikologi Vol.1, No.2, Mei 2020, hlm 68
} 
competent authorities can bring legal proceedings. Law enforcement is performed in a humane and solution way, in order not to create opposition in the community. ${ }^{4}$

Therefore, in this paper the author wants to explain the efforts that law enforcers can make in handling cases of forcibly taking the corpse of a COVID19 patient by the patient's family because they do not agree to a funeral with the health protocol for handling COVID-19.

\section{Research Methods}

This type of study is concise analysis of normative law. The research uses secondary data in the form of basic legal materials, secondary legal materials, and tertiary legal materials. Data collection techniques are conducted through study of legal content literature in normative legal science. Tangible content operations production to systematize written legal documents. In this situation, the analysis of legal materials is carried out by grouping according to the classification of legal materials and systematically and logically documenting the results of the study, indicating that there are relations and linkages between legal materials and other legal materials in order to provide summary of the research results. The legal content is then evaluated and the rule interpreted. ${ }^{5}$

\section{Discussion}

Fear, confusion and fear of the risks of COVID-19 by the public make the pandemic's already poor conditions even worse. They will behave out of control and can jeopardize the health and security of themselves and other communities as a result of their acts. The most prominent example of this situation is the case of compulsory collection of COVID-19 from the hospital's bodies of patients under surveillance (PDP). Such events, which have happened many times, awaken our consciousness of how something has gone horribly wrong in the last few weeks. As reported by social media in Makassar, South Sulawesi, the incident took place at three separate hospitals at the same time last week, namely Labuang Baji Hospital, Dadi Hospital, and Stella Maris Hospital. Other regions, such as Kolaka, Southeast Sulawesi; Bekasi, West Java; Tuban and Surabaya, East Java, have encountered similar cases. By fact, the patients who die in the hospital are under observation. Previously they had similar characteristics to the COVID19 symptoms, such as: high fever, cough, runny nose, inflammation and/or shortness of breath, and showed little improvement when therapy was offered. Using the swab test process, the results of the specimen test can not be identified immediately when the patient dies but wait a few days before. With the features

\footnotetext{
${ }^{4}$ Intaniasari, Kirana, Gross Split Contract Framework Regulation on the Caring for People, Jurnal Bestuur Vol. 8, Issue 2, December, 2020.

${ }^{5}$ Kirana Intaniasari, Gross Split Contract Framework Regulation on the Caring for People, Jurnal Bestuur Vol. 8, Issue 2, December, 2020. hlm 99
} 
of these symptoms, the patient must be buried by the hospital's COVID-19 burial procedure.

Nevertheless, the patient's family insisted on physically reclaiming their family members' bodies which should have been buried with the COVID-19 body handling procedure, where other people would not approach until they have worn full Personal Protective Equipment (PPE). When the protocol is broken, it may result in the virus taking the family. In the midst of the still raging COVID19 pandemic, we are watching this trend that has become viral on social media, and even the entire planet. What we are asking is the situation that is the root cause of the incident between the indifference, indifference or ignorance of the society? This is within the Police's jurisdiction to proceed by prosecution and review on this matter. And it puts public health at risk. We therefore continue to help the security forces that are dealing with the laws of all the perpetrators of forcible taking of bodies. ${ }^{6}$

Law enforcement instruments for this are available. For example, Article 93 of Law No. 6 of 2018 concerning Health Quarantine in conjunction with Article 214 and Article 335 of the Criminal Code, with the threat of a sentence of up to 7 (seven) years in prison for the perpetrator can be a reference. Those who are involved in the act of coercion must also be tested with a swab test and tracing with whoever they have had contact with. The chain of transmission must be identified and broken so that transmission does not spread. The security apparatus, especially the police, is to ensure this. Given the recurring incidents, security forces and hospitals need to be more anticipatory. It is important for hospitals to improve coordination with security forces in anticipation of similar incidents. The pandemic development curve is not yet sloping. Don't let the burden of doctors and nurses in the hospital continue to increase. Forced collection of bodies due to ignorance, incomprehension, and indifference to the dangers of COVID-19 can no longer be tolerated.

Efforts that can be made by law enforcers in cases of forcible collection of bodies by the family include participating in providing education and outreach to the public regarding the dangers of carrying COVID-19 bodies without established procedures and carrying out legal processes with strict norms to give effect deter the perpetrators of forcibly taking the body of COVID-19. In this case, an effective socialization method is needed so that the public understands the dangers of COVID-19, especially regarding the handling of bodies. For example, socialization with virtual media so that patients or the public better understand the impact that occurs when the body is taken away and not treated according to health protocols. The security apparatus has a feature that can be used to approach and socialize differently when an outbreak occurs. Indonesia is a

${ }^{6}$ Fadhillah, Harif, et.all "Regulation of Health Workers in the Legistlation and the Principle of Legal Certainty," Soepra Jurnal Hukum Kesehatan Vol. 05 No. 1, 2019 
storehouse of local values. Some people uphold these local values. We cannot deny the diversity of local values. We can't get rid of local values on the pretext of our formal rules. Law enforcement officials must also understand local values so that they understand what to do with handling when a problem occurs. ${ }^{7}$

That the procedures for handling the COVID-19 body must refer to Law Number 16 of 2018 concerning Health Quarantine and the Circular of the Directorate General of Disease Prevention and Control of the Ministry of Health Number 482 of 2020 concerning Guidelines for Preparedness for Facing COVID19. The protocol for managing the bodies of COVID-19 patients and also for bodies with PDP status who have not received the results of laboratory tests for COVID-19 include the following: 8

a. HCWs should exercise standard precautions when handling patients who have died from infectious diseases.

b. PPE must be used by the officer as attached (attachment 17) who handles the body if the patient dies.

c. The body must be completely wrapped in an impermeable body bag before being transferred to the mortuary.

d. Do not leak bodily fluids that contaminate the outside of the body bag.

e. Move as soon as possible to the mortuary after death.

f. If the patient's family wants to see the body, it is permissible to do so before the body is put into the body bag using PPE.

g. The officer must provide an explanation to the family about special handling for corpses who died with infectious diseases. Religious, customs and cultural sensitivities must be considered when a patient with an infectious disease dies.

h. The body should not be embalmed or injected with preservatives.

i. If it is to be autopsied, it must be done by a special officer, if allowed by the family and the Hospital Director.

j. Wrapped bodies may not be opened again.

$\mathrm{k}$. The body should be delivered by a special hearse.

1. The corpse should not be more than 4 (four) hours buried in the body's review.

If the community remains adamant or forcibly keeps bringing home bodies that have been infected with COVID-19 or who are still Patients Under Supervision (PDP) whose swab test results have not come out without paying attention to the protocol for handling the bodies of COVID-19 patients, the community can be subject to legal sanctions. according to the articles as follows

7 Nasution. Mirza. 2020. Politik Hukum dan Regulasi-Regulasi Penanganan Covid-19. Disampaikan dalam Webinar APHTN-HAN Sumatera Utara, 2 Juni 2020

${ }^{8}$ Kementerian Kesehatan Republik Indonesia. 2020. Pedoman Pencegahan Dan Pengendalian Coronavirus Disease (Covid-19) Revisi Ke-4. Jakarta : Direktorat Jenderal Pencegahan Dan Pengendalian Penyakit. 
article 93 of Law Number 6 of 2018 concerning Health Quarantine every person who does not comply with the implementation of Health Quarantine as referred to in Article 9 paragraph (1) and / or obstructs the implementation of Health Quarantine so as to cause a Public Health Emergency will be sentenced to imprisonment of a maximum of 1 (one) year and / or a maximum fine. Rp. 100,000,000.00 (one hundred million rupiah)" ${ }^{9}$

Article 211 which reads "Anyone who by force or threat of violence forces an official to perform an official act or not to perform an official official act, shall be punished by a maximum imprisonment of four years". Article 212 which reads "Whoever with violence or threats of violence against an official who is carrying out a legitimate task, or person who according to statutory obligations or at the request of an official to provide assistance to him, is threatened for fighting an official, with a maximum imprisonment of one year. four months or a maximum fine of four thousand five hundred rupiahs".

Article 214 which reads:

a. In paragraph (1) which reads "Coercion and resistance based on articles 211 and 212 if committed by two or more persons in association, shall be punished with a maximum imprisonment of seven years".

b. In paragraph (2) it reads "The guilty one is imposed:

1) A maximum imprisonment of eight years and six months, if the crime or other act at that time resulted in injuries;

2) The maximum imprisonment is twelve years, if serious injuries are caused;

3) A maximum imprisonment of five helas years, if the person dies.

So that the Police can ensnare the perpetrators of forcibly taking the body of Covid-19 with these articles, such as the perpetrators at Labuang Baji Hospital in Makassar, South Sulawesi who have been named as suspects. With firmness in upholding the rule of law in accordance with applicable laws, it is hoped that it can provide a deterrent effect to people who always violate legal rules in handling COVID-19 in Indonesia.

\section{Conclusion}

That many people violated the rule of law during the COVID-19 pandemic outbreak that hit the country of Indonesia. From violations of general criminal law laws and health law laws. It is as if people do not care about the dangers of the COVID-19 virus in everyday life. Such as the collection of bodies exposed to COVID-19 by force by the family, which causes new clusters of people exposed to COVID-19 to increase. Given the very fast transmission of the COVID-19 virus through droplets that come out of the mouths of COVID-19 patients. Law

${ }^{9}$ Undang-undang Nomor 6 Tahun 2018 tentang Karantina Kesehatan 
enforcement officials, especially the Police of the Republic of Indonesia, must act firmly against the public who violate the prevailing laws in the midst of the COVID-19 pandemic, especially those who violate the Health Quarantine Law regarding the handling protocol for COVID-19 so that the public is deterred from the actions that have been done so that they do not followed by other communities. In this way, it is hoped that the spread of the COVID-19 virus can be suppressed so that the COVID-19 pandemic in the country of Indonesia will soon be completed.

\section{REFERENCE}

Siringoringo, Valeri M.P. et.all, Pengaturan Perlindungan Hukum Hak-Hak Pasien Dalam Peraturan Perundang-Undangan Tentang Kesehatan di Indonesia, Diponegoro Law Journal Volume 6, Nomor 2, Tahun 2017

Fadhillah, Harif, et.all "Regulation of Health Workers in the Legistlation and the Principle of Legal Certainty," Soepra Jurnal Hukum Kesehatan Vol. 05 No. 1, 2019,

Jaelani, Abdul Kadir, Implementasi Daluarsa Gugatan Dalam Putusan Peradilan Tata Usaha Negara di Indonesia, Pena Justisia: Media Komunikasi dan Kajian Hukum, Volume 18, No.2, 2019

Supriadi, Wila Chandrawila 2001. Hukum Kedokteran, Bandung: Mandar Maju.

Handayani, I Gusti Ayu Ketut Rachmi, et.all, Model Pelaksanaan Putusan Mahkamah Konstitusi yang Eksekutabilitas Dalam Pengujian Peraturan Perundang-Undangan di Indonesia, Jurnal Bestuur Vol.VII, Issue.1, Agustus, 2019

Sumardjono, Maria SW. 2014, Metodologi Penelitian Ilmu Hukum, Gadjah Mada Press, Yogyakarta.

Akhmaddhian, Suwari. Discourse on Creating a Special Environmental Court in Indonesia to Resolve Environmental Disputes, Jurnal Bestuur Vol. 8, Issue 2, December, 2020.

Pane, E \& Yanis, A.M, Reconstruction of Mining Policies on Justice in Lampung Province, Jurnal Bestuur Vol. 8, Issue 2, December, 2020.

Soekanto, Soerjono 2018, Penelitian Hukum Normatif Suatu Tinjauan Singkat, Rajawali Press, Jakarta.

Arikunto, Suharsimi 2018, Prosedur Penelitian Suatu Pendekatan, Rineka Cipta, Jakarta.

Saputra, Rian, Development of Creative Industries as Regional Leaders in National Tourism Efforts Based on Geographical Indications, Jurnal Bestuur Vol. 8, Issue 2, December, 2020.

Nasution. Mirza. 2020. Politik Hukum dan Regulasi-Regulasi Penanganan Covid-19. Disampaikan dalam Webinar APHTN-HAN Sumatera Utara, 2 Juni 2020

Hanum, W.N, Setting of Earth Oil Management in Old Wells Based on the Principle Social Justice, Jurnal Bestuur Vol. 8, Issue 2, December, 2020.

Hamzah, M. Guntur 2020. Konstitusi dan Kebijakan Publik dalam Penyelamatan Kehidupan Bersama. Disampaikan pada Webinar Nasional APHTN-HAN Sumatera Utara. Selasa, 2 Juni 2020

Yuliana. 2020. Corona Virus Diseases (Covid-19): sebuah tinjuan literatur. Wellness And Healthy Magazine Vol.2, No.1, Februari (187-192). 
Ivan Muhammad Agung. Memahami Pandemi Covid-19 dalam Perspektif Psikologi Sosial. Psikobuletin: Buletin Ilmiah Psikologi Vol.1, No.2, Mei 2020.

Intaniasari, Kirana, Gross Split Contract Framework Regulation on the Caring for People, Jurnal Bestuur Vol. 8, Issue 2, December, 2020.

Gunawan, Said, The Principle of Control of Non Primary Gun System of the Indonesian National Army Protect Soldiers, Jurnal Bestuur Vol. 8, Issue 2, December, 2020.

Luthviati, R.D, The Role of Local Governments in the Defense of Leading Products, Jurnal Bestuur Vol. 8, Issue 2, December, 2020.

Abdul Kadir Jaelani, "Implementasi Daluarsa Gugatan Dalam Putusan Peradilan Tata Usaha Negara Di Indonesia", Jurnal Pena Justisia, Vol.18, Nomor 2 Tahun 2019.

Nurika Latiff Hikmawati “Efektivitas Penerapan Sanksi Pidana Penjara Terhadap Anak Yang Melakukan Tindak Pidana", Jurnal Pena Justisia, Vol.18, Nomor 2 Tahun 2019.

Miftahur Rahman Hakim, Nur Kholidah, "Hak Merek Sebagai Jaminan Gadai Untuk Permodalan Umkm Industri Kreatif Kerajinan Batik", Jurnal Pena Justisia, Vol.18, Nomor 2 Tahun 2019.

Vidya Noor Rachmadini “Perlindungan Hukum Bagi Investor Dalam Pasar Modal Menurut Undang-Undang Pasar Modal Dan Undang-Undang Otoritas Jasa Keuangan", Jurnal Pena Justisia, Vol.18, Nomor 2 Tahun 2019. 